\title{
Comparison of published palaeoclimate records suitable for reconstructing annual to sub-decadal hydroclimatic variability in eastern Australia: implications for water resource management and planning
}

\author{
Anna L. Flack ${ }^{1}$, Anthony S. Kiem ${ }^{1}$, Tessa R. Vance ${ }^{2, i}$, Carly R. Tozer ${ }^{2,3, \mathbf{i}}$, and Jason L. Roberts ${ }^{4}$ \\ ${ }^{1}$ Centre for Water, Climate and Land (CWCL), Faculty of Science, University of Newcastle, Callaghan, NSW, Australia \\ ${ }^{2}$ Institute for Marine and Antarctic Studies, University of Tasmania, Hobart, Tasmania, Australia \\ ${ }^{3}$ CSIRO Oceans and Atmosphere, Hobart, Tasmania, Australia \\ ${ }^{4}$ Australian Antarctic Division, Kingston, Tasmania, Australia

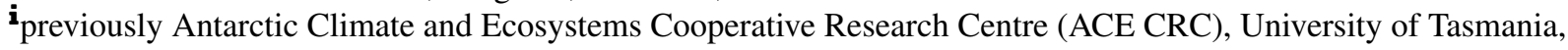 \\ Hobart, Tasmania, Australia
}

Correspondence: Anthony S. Kiem (anthony.kiem@newcastle.edu.au)

Received: 22 June 2020 - Discussion started: 30 June 2020

Revised: 12 October 2020 - Accepted: 12 October 2020 - Published: 29 November 2020

\begin{abstract}
Knowledge of past, current, and future hydroclimatic risk is of great importance. However, like many other countries, Australia's observed hydroclimate records are at best only $\sim 120$ years long (i.e. from $\sim 1900$ to the present) but are typically less than $\sim 50$ years long. Therefore, recent research has focused on developing longer hydroclimate records based on palaeoclimate information from a variety of different sources. Here we review and compare the insights emerging from 11 published palaeoclimate records that are relevant for annual to sub-decadal hydroclimatic variability in eastern Australia over the last $\sim 1000$ years. The sources of palaeoclimate information include ice cores, tree rings, cave deposits, and lake sediment deposits. The published palaeoclimate information was then analysed to determine when (and where) there was agreement (or uncertainty) about the timing of wet and dry epochs in the pre-instrumental period (1000-1899). The occurrence, frequency, duration, and spatial extent of pre-instrumental wet and dry epochs was then compared to wet and dry epochs since 1900. The results show that instrumental records ( 1900-present) underestimate (or at least misrepresent) the full range of rainfall variability that has occurred, and is possible, in eastern Australia. Even more disturbing is the suggestion, based on insights from the published palaeoclimate data analysed, that $71 \%$ of the pre-instrumental period appears to have no equivalent
\end{abstract}

in the instrumental period. This implies that the majority of the past 1000 years was unlike anything encountered in the period that informs water infrastructure, planning, and policy in Australia. A case study, using a typical water storage reservoir in eastern Australia, demonstrates that current water resource infrastructure and management strategies would not cope under the range of pre-instrumental conditions that this study suggests has occurred. When coupled with projected impacts of climate change and growing demands, these results highlight some major challenges for water resource management and infrastructure. Though our case study location is eastern Australia, these challenges, and the limitations associated with current methods that depend on instrumental records that are too short to realistically characterise interannual to multi-decadal variability, also apply globally.

\section{Introduction}

Knowledge of drought and flood history is of great importance and has many implications for current and future water resource management. To date, methods to quantify drought/flood frequency and risk have relied primarily on instrumental records. However, recent research demonstrates 
that the instrumental period is not long enough to obtain a true indication of the variability possible or the risk of extreme hydrological events (e.g. prolonged drought or flood dominated epochs) in, for example, the following locations:

- Australia (e.g. Gallant and Gergis, 2011; Ho et al., 2014; Allen et al., 2015a, b; Ho et al., 2015a, b; Vance et al., 2015; Tozer et al., 2016, 2018; Dixon et al., 2017, 2019; Kiem et al., 2020);

- Asia (e.g. Davi et al., 2013; Feng et al., 2013; Pederson et al., 2014; Nguyen and Galelli, 2018; Rao, 2018; Wang et al., 2019);

- the United States of America (USA; e.g. Cook et al., 2004; Littell et al., 2016; Martin et al., 2019; England et al., 2019; Robeson et al., 2020);

- Europe (e.g. Cook et al., 2015; Perşoiu et al., 2017; Hanel et al., 2018);

- South America (e.g. Lara et al., 2008; Urrutia et al., 2011; Barria et al., 2018; Fernández et al., 2018).

Like many other countries, most instrumental rainfall records in Australia only exist for $\sim 120$ years at best, and streamflow records longer than $\sim 50$ years are rare. During this short time, Australia has experienced some serious droughts and floods. For example, the Millennium drought, which lasted from $\sim 1997$ to 2010, and during which urban and rural water resources in eastern Australia were put under significant stress (Verdon-Kidd and Kiem, 2009; Kiem et al., 2016), and the 2010-2011 Queensland floods during which the Wivenhoe Dam reached capacity, overflowed, and destroyed dozens of properties (http://www.floodcommission.qld.gov.au/ last access: 12 October 2020; Van den Honert and McAneney, 2011; McMahon and Kiem, 2018). To enable design and implementation of robust adaptation and management plans, it is important to properly understand the chance of similar or worse droughts and floods happening again. This requires an understanding about, and quantification of, the interannual to multi-decadal variability beyond that seen in the instrumental records (e.g. England et al., 2019; Natural Resources Canada, 2019; Armstrong et al., 2020; Kiem et al., 2020)

Climate variability in the pre-instrumental past can be inferred from palaeoclimate proxies. However, in the Southern Hemisphere and eastern Australia in particular, there are limited palaeoclimate records available, especially in comparison to the Northern Hemisphere (Ho et al., 2014; Neukom et al., 2014). Therefore, it is important to determine how the few palaeoclimate records that exist, and are relevant in terms of variables reconstructed and temporal or spatial resolution, can be best utilised to infer pre-instrumental hydroclimatic histories for locations within eastern Australia. Pre-instrumental hydroclimate reconstructions for Australia have been attempted using palaeoclimate proxies including tree rings, ice cores, corals, and lake sediments (e.g. Lough,
2011; Vance et al., 2013; Barr et al., 2014; Allen et al., 2015a; Palmer et al., 2015; Allen et al., 2017). Due to the lack of in situ (local) proxies in Australia, many of these reconstructions rely on using remote proxies (i.e. proxies outside of Australia or the catchment of interest). Remote proxies utilise a climate teleconnection between the location of the proxy record and the location of the target climate variable (e.g. a water catchment).

Currently there is no comprehensive comparison of where and when the few palaeoclimate records that exist for Australia agree or disagree with respect to pre-instrumental hydroclimatic conditions for eastern Australia. This study reviews and compares the insights emerging from 11 published palaeoclimate records that are relevant for annual to subdecadal hydroclimatic variability in eastern Australia over the last $\sim 1000$ years. Based on where and when the preinstrumental records agree, the occurrence, frequency, duration, and spatial extent of pre-instrumental (1000-1899) wet and dry epochs are inferred, and this is then compared with the same characteristics derived from the instrumental period (1900-1999). A case study, using a typical water storage reservoir in eastern Australia, then demonstrates some implications of the insights emerging from the pre-instrumental data and discusses the challenges posed for water resources management and planning in a variable and changing climate. Though our case study location is eastern Australia, these challenges, and the limitations associated with current methods that depend on instrumental records that are too short to realistically characterise interannual to multi-decadal variability, also apply globally.

\section{Selecting published palaeoclimate records that are relevant to annual to sub-decadal hydroclimatic variability in eastern Australia}

Palaeoclimate information can be sourced from local or remote proxies. Local proxies provide climate records directly from or applicable to a target location, for example cave deposits within a study region/catchment or local tree ring records (e.g. McDonald et al., 2007; Heinrich et al., 2009; Allen et al., 2015b; Ho et al., 2015b). Remote proxies are located outside the region/catchment of interest and maybe outside of Australia (e.g. Vance et al., 2015; Palmer et al., 2015).

Table 1 shows the 11 palaeoclimate records that were selected and analysed in this study. The palaeoclimate records used were selected from palaeoclimate information available (i.e. published) at the time of study, based on the following criteria:

- Spatial extent. Records must be sourced from locations within eastern Australia (if a local record) or be relevant to eastern Australia (if a remote record). Figure 1 shows the spatial extent (or relevant location) of the palaeoclimate records used in this study. Figure 1 also indicates 
the type of proxy used and the type of information provided. The information may be in the form of a rainfall/streamflow reconstruction (or inference) or an indication of dry or wet epochs over time.

- Temporal resolution. Records with annual resolution were preferred (nine out of 11 records); however, two records with $\sim 4-5$ year temporal resolution were also used as this is consistent with this study's focus on subdecadal hydroclimatic variability.

- Time period covered. Records used need to provide data for some or all of the 1000-1999 study period. Figure 2 shows the temporal coverage of the 11 chosen palaeoclimate records.

- Hydroclimatic significance. Records used need to provide (i) hydroclimatic information such as precipitation or streamflow or (ii) information that is related to hydroclimatic variability in eastern Australia, e.g. reconstructions of influential large-scale ocean-atmospheric processes (El Niño-Southern Oscillation - ENSO; Interdecadal Pacific Oscillation - IPO; Pacific Decadal Oscillation - PDO).

- Availability and accessibility. Records used need to be readily available (i.e. published) as dated time series so that wet/dry epochs can be easily determined.

\section{Creating a composite index of wet/dry epochs based on where/when the majority of pre-instrumental records agree}

Each of the selected palaeoclimate records shown in Table 1 and Figs. 1 and 2 were analysed to determine the occurrence of wet, dry, and neutral epochs based on a 5-yearly temporal resolution. The focus is on prolonged (5-yearly or greater) wet and dry periods as these are the most challenging for water resource management and planning (Kiem and Franks, 2004; Johnson et al., 2016; Kiem et al., 2016).

The process for determining wet, dry, and neutral 5-year periods involved comparing the value for each 5-year period from an individual palaeoclimate record with the average value across the entire period for which the palaeoclimate record had information available. If the value for a given 5year period was more than $20 \%$ above (below) average, then that 5-year period was classed as wet (dry). All other 5-year periods were classed as neutral (i.e. neither wet or dry; refer to Sect. S1 in Supplement for the complete wet/dry/neutral time series for all selected palaeoclimate records).

The insights emerging from each individual palaeoclimate record were then compared to identify if/when there was consensus about hydroclimatic conditions. As documented in previous studies (e.g. Ho et al., 2015a; Tozer et al., 2016, 2018; Dixon et al., 2017, 2019; Zhang et al., 2018), and as

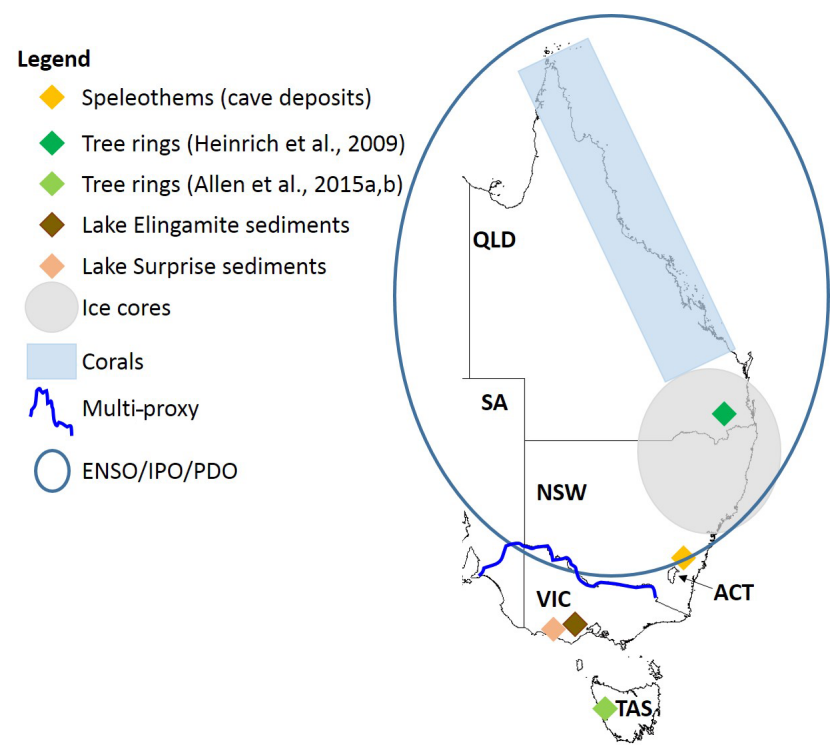

Figure 1. Location map of selected palaeoclimate reconstructions for Queensland (QLD), New South Wales (NSW), the Australian Capital Territory (ACT), Victoria (VIC), Tasmania (TAS), and South Australia (SA). For remote palaeoclimate records, the map indicates where the studies listed have found significant relationships/impacts, while for local records the map shows the actual location of the proxy (refer to Table 1 for further details on the local and remote palaeoclimate records used in this study).

evident from Sect. S1 in the Supplement, there are numerous sources of uncertainty associated with palaeoclimate records, and a lack of agreement across different sources of palaeoclimate information is common. However, there are also instances of agreement, and it is these periods where multiple lines of independent evidence agree that we focus on here.

A wet/dry composite index is developed which identifies 5-year periods in which the majority of palaeoclimate records (i.e. six or more) analysed here agree were wet or dry (Fig. 3). Where there is a lack of information, or where there is no clear agreement, the 5-year period is classed as neutral to indicate it is unclear what the hydroclimatic conditions were during that 5-year period (i.e. no consensus across the palaeoclimate records analysed). Three versions of the wet/dry composite index were calculated, namely one using all palaeoclimate records (top of Fig. 3), one using just local palaeoclimate records (middle of Fig. 3), and one using just remote palaeoclimate records (bottom of Fig. 3). It is acknowledged that more sophisticated methods for using palaeoclimate data exist and that the composite index of 5 -year wet/dry epochs removes the ability to gain insights into (a) interannual variability (e.g. a single very wet year in an overall dry spell or vice versa) and (b) spatial variability in hydroclimatic conditions across the study area (e.g. a palaeoclimate record correctly identifying wet conditions for a certain location in the study area and another palaeoclimate record correctly identifying dry conditions for a different lo- 
Table 1. Published palaeoclimate records used in this study. Note: El Niño-Southern Oscillation - ENSO; Interdecadal Pacific Oscillation IPO; Pacific Decadal Oscillation - PDO.

\begin{tabular}{|c|c|c|c|c|c|}
\hline & Source of record & $\begin{array}{l}\text { Relevant location } \\
\text { within eastern } \\
\text { Australia }\end{array}$ & Authors & $\begin{array}{l}\text { Temporal } \\
\text { resolution }\end{array}$ & Further details \\
\hline \multirow[t]{5}{*}{$\begin{array}{l}\text { Local } \\
\text { records }\end{array}$} & $\begin{array}{l}\text { Speleothems } \\
\text { (cave deposits) }\end{array}$ & $\begin{array}{l}\text { Wombeyan Caves } \\
\text { near Sydney, NSW }\end{array}$ & $\begin{array}{l}\text { Ho et al. }(2015 b) \text {, } \\
\text { based on earlier } \\
\text { work by McDonald } \\
\text { et al. }(2007)\end{array}$ & Annual & $\begin{array}{l}\text { We use the annually resolved } \\
\text { two-state aridity index (dry or } \\
\text { not dry) }\end{array}$ \\
\hline & Tree rings & $\begin{array}{l}\text { Lamington National } \\
\text { Park in southeast } \\
\text { Queensland }\end{array}$ & $\begin{array}{l}\text { Heinrich et al. } \\
(2009)\end{array}$ & Annual & $\begin{array}{l}\text { Reconstructed precipitation } \\
\text { (wet or dry) }\end{array}$ \\
\hline & Tree rings & Western Tasmania & $\begin{array}{l}\text { Allen et al. } \\
(2015 \mathrm{a}, \mathrm{b})\end{array}$ & Annual & $\begin{array}{l}\text { Reconstructed streamflow } \\
\text { (wet or dry) }\end{array}$ \\
\hline & Lake sediments & $\begin{array}{l}\text { Lake Elingamite, } \\
\text { northern Victoria }\end{array}$ & $\begin{array}{l}\text { Barr et al. } \\
(2014)\end{array}$ & $\sim 4$ years & $\begin{array}{l}\text { Diatom (microfossil) presence } \\
\text { and abundance used to infer } \\
\text { low (wet) or high (dry) } \\
\text { conductivity }\end{array}$ \\
\hline & Lake sediments & $\begin{array}{l}\text { Lake Surprise, } \\
\text { northern Victoria }\end{array}$ & $\begin{array}{l}\text { Barr et al. } \\
(2014)\end{array}$ & $\sim 5$ years & \\
\hline \multirow[t]{6}{*}{$\begin{array}{l}\text { Remote } \\
\text { records }\end{array}$} & Ice cores & Eastern Australia & $\begin{array}{l}\text { Vance et al. } \\
(2015)\end{array}$ & Annual & $\begin{array}{l}\text { Reconstructed IPO and associ- } \\
\text { ated rainfall variability }\end{array}$ \\
\hline & Corals & $\begin{array}{l}\text { Tropical eastern } \\
\text { Australia }\end{array}$ & $\begin{array}{l}\text { Hendy et al. (2003); } \\
\text { Lough et al. } \\
(2011)\end{array}$ & Annual & $\begin{array}{l}\text { Presence (wet) and absence } \\
\text { (dry) of luminescence lines; } \\
\text { reconstructed rainfall anoma- } \\
\text { lies (positive - wet; } \\
\text { negative - dry) }\end{array}$ \\
\hline & $\begin{array}{l}\text { Multi-proxy (tree } \\
\text { rings and coral) }\end{array}$ & $\begin{array}{l}\text { Murray-Darling } \\
\text { rivers }\end{array}$ & $\begin{array}{l}\text { Gallant and Gergis } \\
(2011)\end{array}$ & Annual & Reconstructed streamflow \\
\hline & $\begin{array}{l}\text { Multi-proxy (correla- } \\
\text { tion with PDO derived } \\
\text { from Chinese historical } \\
\text { documents) }\end{array}$ & $\begin{array}{l}\text { Murray-Darling } \\
\text { rivers }\end{array}$ & $\begin{array}{l}\text { McGowan et al. } \\
(2009)\end{array}$ & Annual & Reconstructed streamflow \\
\hline & $\begin{array}{l}\text { ENSO/PDO } \\
\text { reconstruction }\end{array}$ & Eastern Australia & $\begin{array}{l}\text { Verdon and Franks } \\
\text { (2006) }\end{array}$ & Annual & $\begin{array}{l}\text { Reconstructed ENSO/PDO } \\
\text { and associated rainfall } \\
\text { variability }\end{array}$ \\
\hline & $\begin{array}{l}\text { ENSO/IPO } \\
\text { reconstruction }\end{array}$ & Eastern Australia & $\begin{array}{l}\text { Buckley et al. } \\
\text { (2019) }\end{array}$ & Annual & $\begin{array}{l}\text { IPO reconstructed from trans- } \\
\text { Pacific tree rings }\end{array}$ \\
\hline
\end{tabular}

cation results in an unrealistic classification of neutral conditions across the whole study area). However, while interannual and spatial variability across the study area are important, the focus here is on (a) persistent (i.e. decadal) wet/dry epochs, as they are what cause the most problems for water resources management and planning, and (b) significant climate events (or shifts) that affect the whole of eastern Australia (i.e. the climate events detected in multiple different types of palaeoclimate records even though the spatial extents, or relevant locations, for the palaeoclimate records are very different, as illustrated in Fig. 1).
To verify the reliability of each wet/dry composite index, we assessed how closely they represent conditions in the instrumental period. The majority of palaeoclimate records clearly identify the second half of the Federation drought (1895-1902), the extremely dry periods of the late 1960s and 1982-1983 (Verdon-Kidd and Kiem, 2009), and the dry IPO positive phase between $\sim 1915$ and $\sim 1942$. Major wet periods can also be seen, such as the 1950s and 1970s, during which several major flood events occurred across New South Wales and Queensland (especially during the La Niña years of 1956 and 1974; e.g. McMahon and Kiem, 2018; 


\begin{tabular}{|c|c|c|c|c|c|c|c|c|c|c|c|c|}
\hline & $\begin{array}{l}\text { Source of } \\
\text { record }\end{array}$ & $\begin{array}{l}\text { Relevant location } \\
\text { within eastern } \\
\text { Australia }\end{array}$ & $1000 \mathrm{~s}$ & $1100 \mathrm{~s}$ & $1200 \mathrm{~s}$ & $1300 \mathrm{~s}$ & $1400 \mathrm{~s}$ & $1500 \mathrm{~s}$ & $1600 \mathrm{~s}$ & $1700 \mathrm{~s}$ & 1800 s & $1900 \mathrm{~s}$ \\
\hline \multirow{5}{*}{$\begin{array}{l}\text { Local } \\
\text { records }\end{array}$} & $\begin{array}{l}\text { Speleothems } \\
\text { (cave deposits) }\end{array}$ & $\begin{array}{l}\text { Wombeyan Caves near } \\
\text { Sydney, NSW }\end{array}$ & \multirow{2}{*}{\multicolumn{10}{|c|}{ 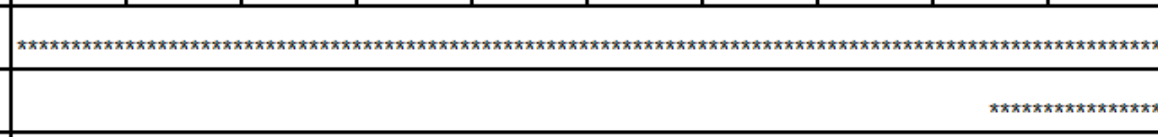 }} \\
\hline & Tree rings & $\begin{array}{l}\text { Lamington National Park } \\
\text { in southeast Queensland }\end{array}$ & & & & & & & & & & \\
\hline & Tree rings & Western Tasmania & \multicolumn{10}{|c|}{ 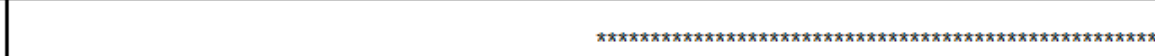 } \\
\hline & Lake sediments & \begin{tabular}{|l|} 
Lake Elingamite, northern \\
Victoria
\end{tabular} & \multicolumn{10}{|c|}{ 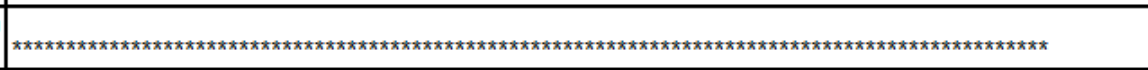 } \\
\hline & Lake sediments & \begin{tabular}{|l|} 
Lake Surprise, northern \\
Victoria
\end{tabular} & \multicolumn{10}{|c|}{ 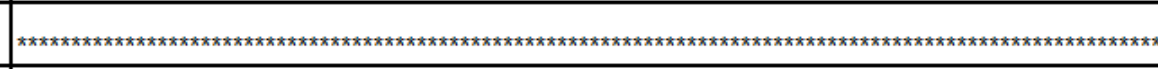 } \\
\hline \multirow{6}{*}{$\begin{array}{l}\text { Remote } \\
\text { records }\end{array}$} & Ice cores & Eastern Australia & \multicolumn{10}{|c|}{ 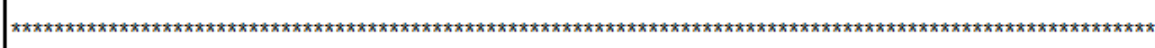 } \\
\hline & Corals & Tropical eastern Australia & \multicolumn{10}{|c|}{ 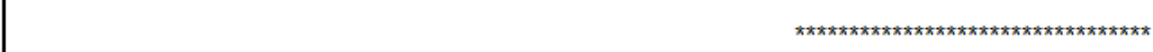 } \\
\hline & Multi-proxy & \begin{tabular}{|l|} 
Murray-Darling rivers \\
(Gallant and Gergis, 2011)
\end{tabular} & \multicolumn{10}{|c|}{ 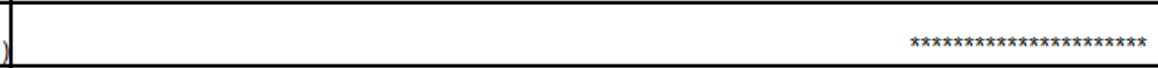 } \\
\hline & Multi-proxy & $\begin{array}{l}\text { Murray-Darling rivers } \\
\text { (McGowan et al., 2009) }\end{array}$ & \multicolumn{10}{|c|}{ 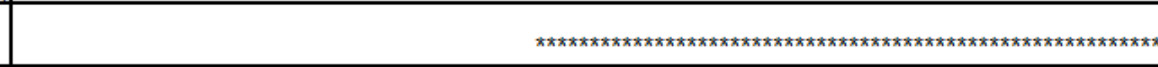 } \\
\hline & $\begin{array}{l}\text { ENSO/PDO } \\
\text { reconstruction } \\
\end{array}$ & $\begin{array}{l}\text { Eastern Australia (Verdon } \\
\text { and Franks, 2006) }\end{array}$ & \multicolumn{10}{|c|}{ 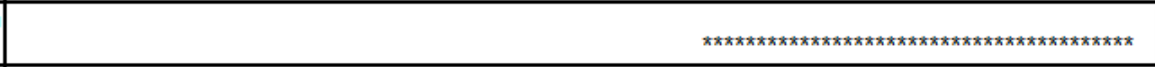 } \\
\hline & $\begin{array}{l}\text { ENSO/IPO } \\
\text { reconstruction } \\
\end{array}$ & $\begin{array}{l}\text { Eastern Australia } \\
\text { (Buckley et al., 2019) }\end{array}$ & \multicolumn{10}{|c|}{ 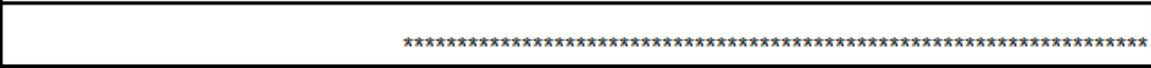 } \\
\hline
\end{tabular}

Figure 2. Time period covered by the published palaeoclimate records used in this study.

Holland et al., 1987). Given that the palaeoclimate data (and the resulting wet/dry composite index) satisfactorily identify known instrumental wet and dry periods, it is reasonable to assume that the pre-instrumental parts of the wet/dry composite index are also realistic. Note, however, that this is based on the assumption of stationarity, which is a potentially flawed but currently a necessary assumption required when reconstructing pre-instrumental data from palaeoclimate proxies (Gallant et al., 2013).

Also highlighted by Fig. 3 is that local and remote reconstructions do not always give the same result. This is expected since remote proxies give information about overarching conditions for a large area (e.g. an ENSO reconstruction) and frequently explain less of the variability in the region of interest than local proxies which record specific information for the local region from which the proxy is sourced (or to which it is directly applicable). This emphasises that, whenever possible, multiple proxies from both remote and local sources should be considered, and that care should be taken when looking to infer location-specific information from remote proxies or any aggregation that includes local or remote proxies that are not specifically developed for the target location. Where and when remote and local proxies disagree also raises interesting questions about why this is the case and points to areas where improvement in our understanding of climate dynamics is required (e.g. Gallant et al., 2013); this is further explored in Sect. 4.3.2.

Despite some obvious differences among the three versions of the wet/dry composite index, there is also some coherence. All three versions of the wet/dry composite index show a generally dry period from $\sim 1000$ to 1150 and a wet period from $\sim 1550$ to 1600 . Both remote and local proxies also indicate that there have been wet and dry epochs in the past that have persisted for significantly longer than wet and dry epochs in the instrumental period (1900-1999). Therefore, despite some differences between the remote and local proxies, the results suggest that the instrumental period may not be a true indicator of the potential for prolonged wet and dry conditions in eastern Australia. Another interesting feature, demonstrated in all three versions of the wet/dry composite index, is that the past $\sim 200$ years appear to show the most variability (i.e. the most frequent shifts between wet and dry conditions). This is consistent with the findings from other studies (e.g. Zhang et al., 2018; Dixon et al., 2019) and again suggests that the last $\sim 200$ years are unusual and that multi-decadal-scale persistence, rather than more frequent fluctuations between wet and dry conditions, has dominated most of the last 1000 years.

\section{Results}

\subsection{Frequency of pre-instrumental wet and dry epochs}

The frequency of wet and dry epochs was determined by dividing the total wet/dry composite time series (top of Fig. 3) into 10 105-year periods (starting every 100 years from 1000 to 1900). Overlapping 105-year periods were chosen in order to identify any wet or dry events that may have occurred across the turn of the century, such as the Federation and Millennium droughts. This allowed for a calculation of the relative difference in and frequencies of wet and dry epochs of the pre-instrumental and the most recent 105-year instrumental period (1895-1999). 

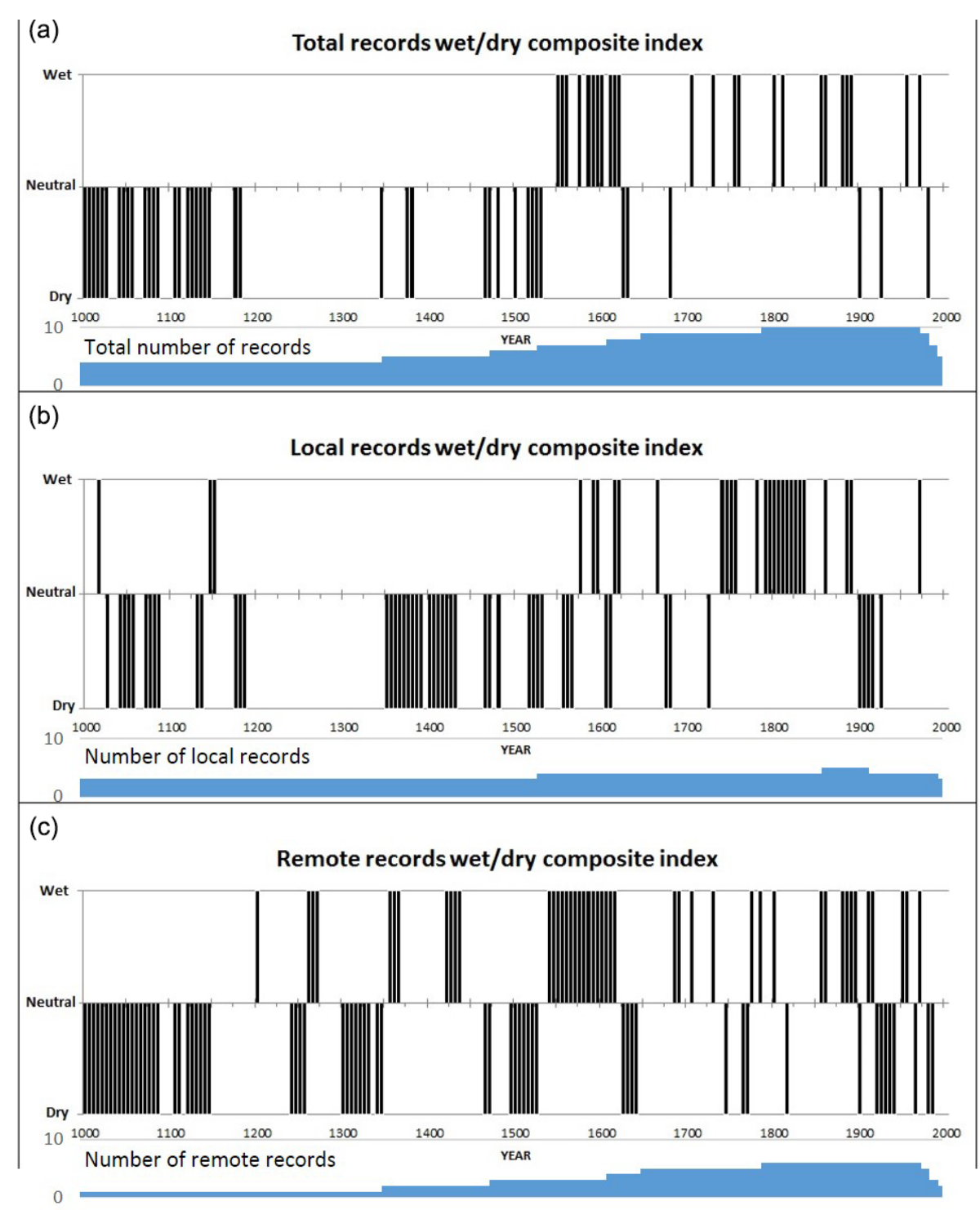

Figure 3. Wet/dry composite index for all palaeoclimate records (a), just local records (b), and just remote records (c). The number of records available for each 5-year period is also shown (11 records in total were used in this study, as per Table 1).

Figure 4 shows the percentage of dry, neutral, and wet years for each 105-year period between 1000 and 1999. It is clear that the most recent 105-year period (1895-1999) does not accurately reflect conditions in any of the other centuries, and that none of the 105-year periods are particularly alike (with the possible exception of 1300-1405 and 14001505). The 1000s, 1100s, and 1400s all experienced a much greater proportion of dry years than the instrumental period, and no wet years, while the 1500s, 1600s, 1700s, and 1800s all recorded a greater proportion of wet years than the instrumental period. Water resource managers therefore need to be cautious when using the instrumental period as a basis for planning and infrastructure design since it is clear that the 105 years from 1895 have a very different distribution of wet and dry years to the previous 9 centuries. Similar conclusions and recommendations were also made in Tozer et al. (2016) for a different study location and using a different methodology and approach.

\subsection{Duration of pre-instrumental wet and dry epochs}

For all individual palaeoclimate records, the instrumental period was compared to the pre-instrumental period to determine if any pre-instrumental conditions had an instrumental period analogue. Instrumental period analogues were identified by listing, for each 5-year instrumental period (i.e. 1900-1904, 1905-1909, etc.), the 5-year pre-instrumental periods in which all palaeoclimate records had exactly the same wet, dry, or neutral classification (as per Sect. S1 in Supplement). Figure 5 shows, where possible, the 5 -year in- 


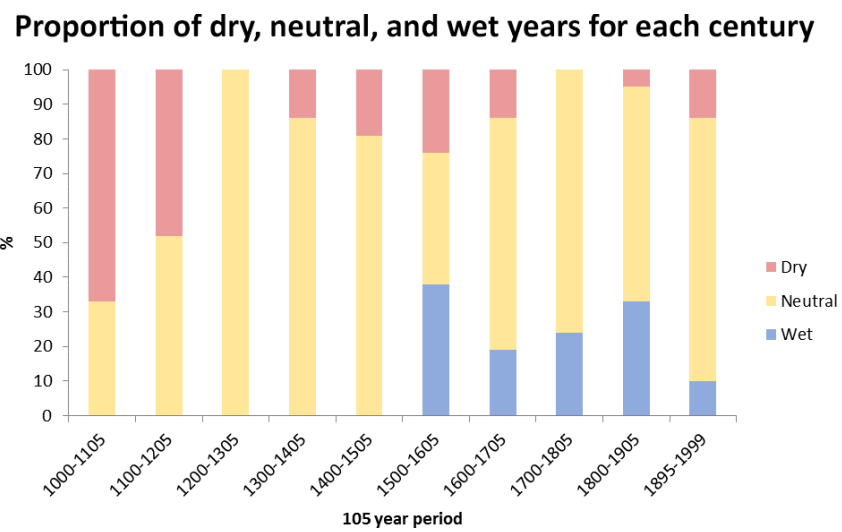

Figure 4. Proportion of dry, neutral, and wet years for each 105year period, starting every 100 years from 1000 to 1895 .

strumental periods that were determined to be equivalent to the pre-instrumental 5-year periods (Sect. S2 in the Supplement lists the actual periods). Figure 5 shows that every 5year instrumental period had at least one equivalent in the pre-instrumental information. However, while there were 53 5 -year pre-instrumental periods identified which had an instrumental equivalent ( $29 \%$ of the pre-instrumental study period), the majority do not have any instrumental analogue. In other words, $71 \%$ of the pre-instrumental period was found to have no equivalent instrumental periods. Hence, for most 5 -year pre-instrumental periods, there is no modern equivalent captured by the instrumental record, meaning that the vast majority of the 900 years from 1000 to 1899 was unlike anything that has been encountered in the period on which all water infrastructure, planning, and policy is based.

Where there were a number of consecutively similar periods, the duration was calculated, allowing for an assessment of whether conditions experienced in the instrumental period have persisted for longer during the pre-instrumental period. Figure 6 shows the duration of pre-instrumental periods found to be equivalent to certain instrumental 5-year periods. As Fig. 6 demonstrates, similar pre-instrumental periods have durations ranging from 5 to 70 years.

The 1900-1904, 1925-1929, and 1980-1984 periods were all considerably dry. As Fig. 6 shows, pre-instrumental conditions similar to these periods have lasted for up to 50 years in the past. For example, 16 periods greater than 5 years between 1000 and 1899 were found that are similar to the dry 1900-1904 period (a period associated with the well-known 1895-1902 Federation drought). This suggests that dry conditions similar to those experienced during the Federation drought have occurred previously for up to 10 consecutive 5year periods, and that there is the potential for dry periods of a similar duration to occur again. Due to the variables reconstructed in some of the proxy studies, the magnitude of these dry periods cannot be determined using these data. However, even slightly drier than average conditions for these durations can have significant effects on water supplies, the environment, and socioeconomic conditions (e.g. Kiem, 2013; Kiem and Austin, 2013; Kiem et al., 2016).

Similarly, 1955-1959 is a known wet period that was associated with significant flooding across much of eastern Australia. A total of 15 periods in the palaeo-record were identified between 1000 and 1899, which demonstrated a similar combination of records as 1955-1959 but had durations ranging from one to 145 -year periods (i.e. 5 to 70 years). Given that wet epochs of these durations have occurred in the past, there is the potential for something similar to happen again in the future. Again, while it is not possible to determine the upper magnitude of these wet events, wet conditions that persist for decades can lead to serious water management issues and significantly elevated flood risk due to the role antecedent catchment conditions play in modulating flood risk (e.g. Kiem et al., 2006; Pui et al., 2011; Johnson et al., 2016).

\subsection{Spatial extent of pre-instrumental wet and dry epochs}

Australian Water Availability Project (AWAP; Jones et al., 2009) rainfall data were used to produce rainfall anomaly maps for eastern Australia. AWAP data are an Australiawide gridded rainfall data set available as monthly rainfall averages and anomalies, extrapolated from gauged daily or monthly rainfall data (Tozer et al., 2012; King et al., 2013). Annual gridded AWAP data were obtained and combined into 5-year periods from 1900 to 1999 (1900-1904, 19051909 , etc.) to produce maps showing 5 year totals relative to the total 5-year average over the instrumental period when AWAP data are available (refer to Sect. S3 in the Supplement for the maps for each 5-year period).

The pre-instrumental 5-year periods previously identified as being equivalent to specific 5-year instrumental periods were then matched to the corresponding maps created using AWAP data. The spatial extent of individual palaeoclimate reconstructions, indicating either wet or dry conditions, was overlaid on the AWAP maps to give an indication of the spatial extent of pre-instrumental wet and dry epochs. Where the spatial extent of palaeoclimate reconstructions matched actual rainfall patterns for 5-year instrumental periods, there is a chance that the pre-instrumental hydroclimatic conditions were also similar. One wet and one dry period will be examined in closer detail (see Fig. 7).

\subsection{Pre-instrumental dry epochs similar to the 1965-1969 drought experienced across most of eastern Australia}

The late 1960s were associated with serious drought conditions for much of eastern Australia. As shown in Fig. 7a, this drought was very widespread but particularly affected eastern Australia between 1964 and 1968. The 1965-1969 drought is chosen rather than the more iconic Federation, 


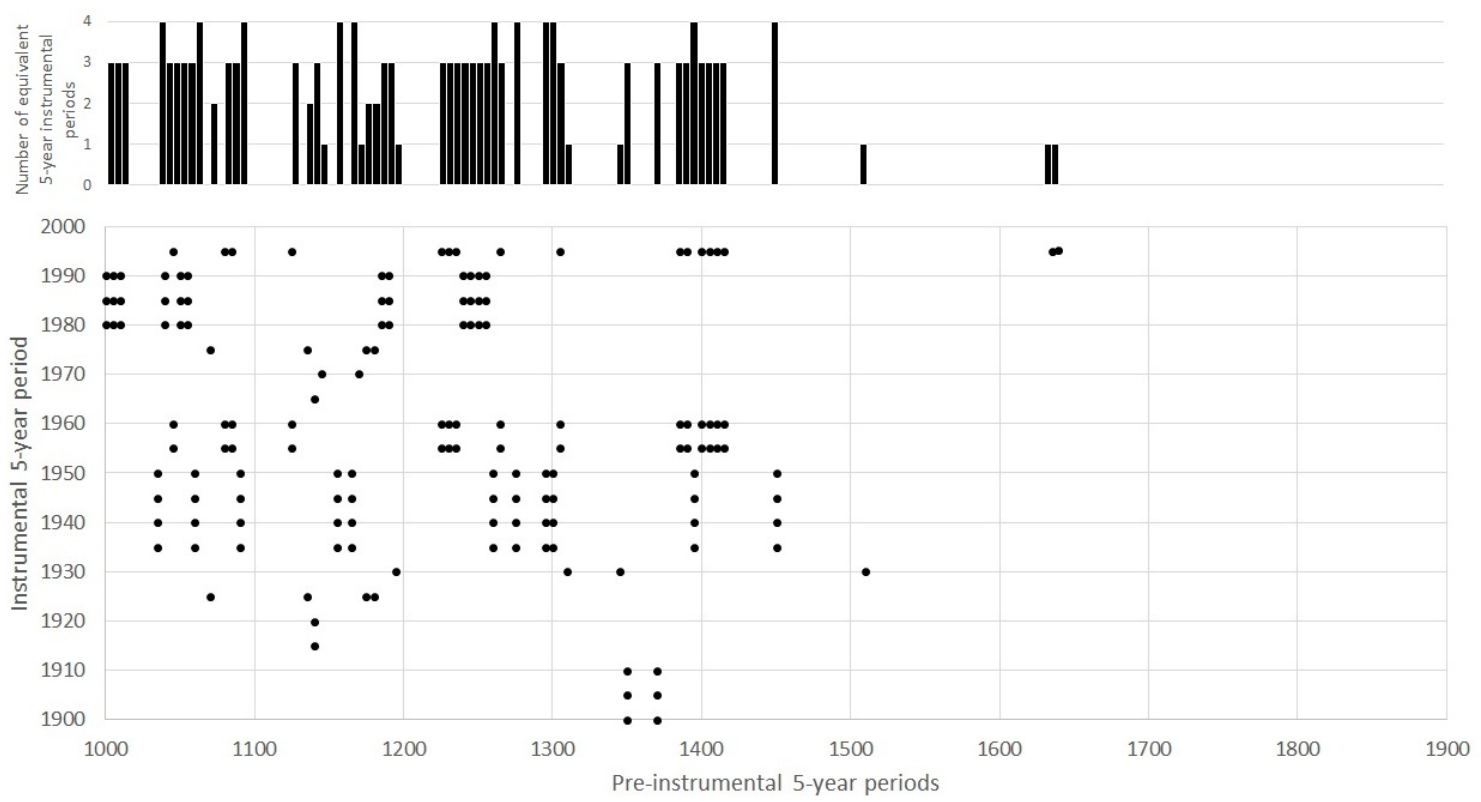

Figure 5. Instrumental equivalents to pre-instrumental 5-year periods.

World War II, or Millennium droughts (Verdon-Kidd and Kiem, 2009) because (i) instrumental data records are incomplete for the Federation and World War II droughts, and (ii) the majority of palaeoclimate records used in this study do not cover the full duration of the Millennium drought.

Our results suggest that the period from 1140 to 1144 is equivalent to 1965-1969. Palaeoclimate records for both of these periods indicate drier conditions, particularly the Wombeyan record (Ho et al., 2015b), the ice core record (Vance et al., 2015), and the Barr et al. (2014) lake sediment records. The areas covered by these records, namely the NSW southern tablelands, southeast Queensland, and the Murray River respectively, can be seen in Fig. 7a as some of the driest areas recorded between 1965 and 1969. The number of similarities found between records when comparing 1965-1969 and 1140-1144 suggest that extreme dry or wet conditions encountered in the instrumental period are not unprecedented. Additionally, this shows that it is possible to estimate the spatial extent of pre-instrumental wet and dry periods if there is a modern analogue available to base an estimate on.

\subsection{Pre-instrumental wet epochs similar to the flood-dominated 1970-1974 period experienced across most of eastern Australia}

The period between 1970 and 1974 was a strong La Niña period, with above-average rainfall for most of eastern Australia. A number of tropical cyclones combined with excessive rainfall caused flooding in Brisbane and Tasmania, and Victoria also experienced its highest recorded rainfall. Fig- ure $7 \mathrm{~b}$ clearly shows widespread, above-average rainfall during this 5-year period.

The majority of local, remote, and total records for 19701974 all indicate wet conditions. According to previous analysis, 1145-1149 and 1170-1174 also experienced similar rainfall conditions. However, the majority of records for these periods do not agree on persistent wet conditions. In 1170-1174, Ho et al. (2015b) and Vance et al. (2015) suggest conditions were dry. However, Fig. $7 \mathrm{~b}$ shows that these records do in fact cover the regions of eastern Australia that were drier between 1970 and 1974. Similarly, in 1170-1174, Barr et al. (2014; Lake Surprise) show wet conditions, and these overlap with the wetter regions in Fig. 7b. Similar trends can also be seen with the other equivalent period of 1145-1149. A low-resolution eastern Australian record (not used here because it did not meet the temporal-resolution criteria) from Stradbroke Island in eastern subtropical Australia also suggests that the mid-1100s were particularly dry (Barr et al., 2019).

This further validates the methods used in this study and shows that the wet/dry composite index displayed in Fig. 3 is likely a conservative estimate of the actual pre-instrumental wet and dry conditions. If this is indeed the case, there is a high chance that extreme rainfall and flood conditions experienced between 1970 and 1974 may have been surpassed by wetter events in the past. As discussed previously, only $29 \%$ of the pre-instrumental study period was found to have an instrumental equivalent, meaning that conditions for the majority of 1000-1899 were unlike anything experienced in the instrumental period. At this stage, there is no way of determining the spatial signature of events that do not have an instrumental analogue, making it difficult to esti- 


\section{Duration of periods equivalent to instrumental periods}

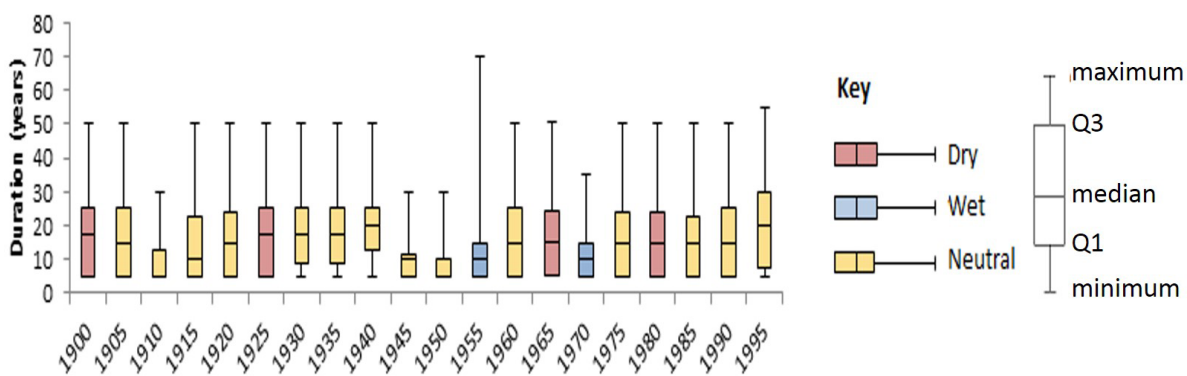

Year

Figure 6. Duration of pre-instrumental periods with similar hydroclimatic conditions to the 5-year periods from the instrumental record. Instrumental periods identified as being wet, dry, or neutral are coloured correspondingly.

mate exactly which areas would be impacted if/when those pre-instrumental wet or dry conditions return. What is certain, however, is that existing water resource planning, infrastructure, and management has been developed based on only $29 \%$ of the hydroclimatic variability that is possible. Furthermore, the reliability of existing water resource and water hazard management systems under conditions experienced in the remaining $71 \%$ of the last 1000 years is currently unknown, and this represents a significant source of vulnerability to our environmental and socioeconomic sustainability.

\subsection{Implications for water resource management and planning: a case study using a typical water storage reservoir from eastern Australia}

The preceding results showed that there is the potential for more extreme and prolonged wet and dry epochs to occur throughout eastern Australia. To gain more of an understanding into exactly what impact these events may have on catchment-scale water resources, the 1000-year total records wet-dry composite index (Fig. 3, top) is used in a model that estimates the water stored (as a percentage of total capacity) in a water storage reservoir. The water storage reservoir is typical of most dams in eastern Australia and it, and the water storage model, is further described in Kiem and Franks (2004). Annual dam capacity is influenced by inputs (rainfall, catchment runoff, and inflow via pumping stations) and outputs (evaporation, spill, and supply to the population). This analysis has assumed conservative conditions, with an initial capacity of $100 \%$. According to Australian standards, dam levels must not be under the critical threshold (30\%) for more than $1 \%$ of the time (Kiem and Franks, 2004).

Based on annual rainfall, the averages for the wettest, driest, and middle input and output values were calculated to give an indicative value for a typical wet, dry, and neutral period. These values are then applied to the 1000-year wet-dry composite index previously developed to produce a 1000year reconstruction of the case study's water storage levels (see Fig. 8). While this dam has obviously not existed for the past 1000 years, this reconstruction provides insight into how water security in the region could be affected if some of the pre-instrumental conditions described previously were to occur again.

Figure 8 clearly identifies the Federation drought as a time of potentially lower dam levels and an intense drought experienced by eastern Australia in 1982-1983 (Verdon-Kidd and Kiem, 2009). This highlights the model's ability to portray realistic results throughout the instrumental period and the limited range of drought and flooding experienced since 1900 , relative to the pre-1900 conditions. This is highlighted by two examples.

The first 200 years (1000-1200) were significantly drier than the most recent century, and during this period, the dam level was constantly below the critical threshold of $30 \%$ capacity.

Apart from dry epochs in the late 1300 s, mid-1400s to the mid-1500s, 1620-1650 and late 1600s, most of the period post-1200 was associated with wet conditions, with the case study showing several extended periods at capacity (e.g. almost 200 years between $\sim 1700$ and 1900 where the reservoir would have been spilling).

Figure 8 shows that this case study reservoir was under the critical threshold of $30 \%$ capacity for $18.5 \%$ of the past 1000 years. Therefore, if conditions similar to any one of these centuries were to take place again, this water catchment area would be placed under significant stress and would need to implement additional water conservation and supply measures.

On the other hand, a dam at capacity for an extended period of time could also pose major issues. For example, Wivenhoe Dam in southeast Queensland reached capacity during the 2010-2011 Queensland floods, and 

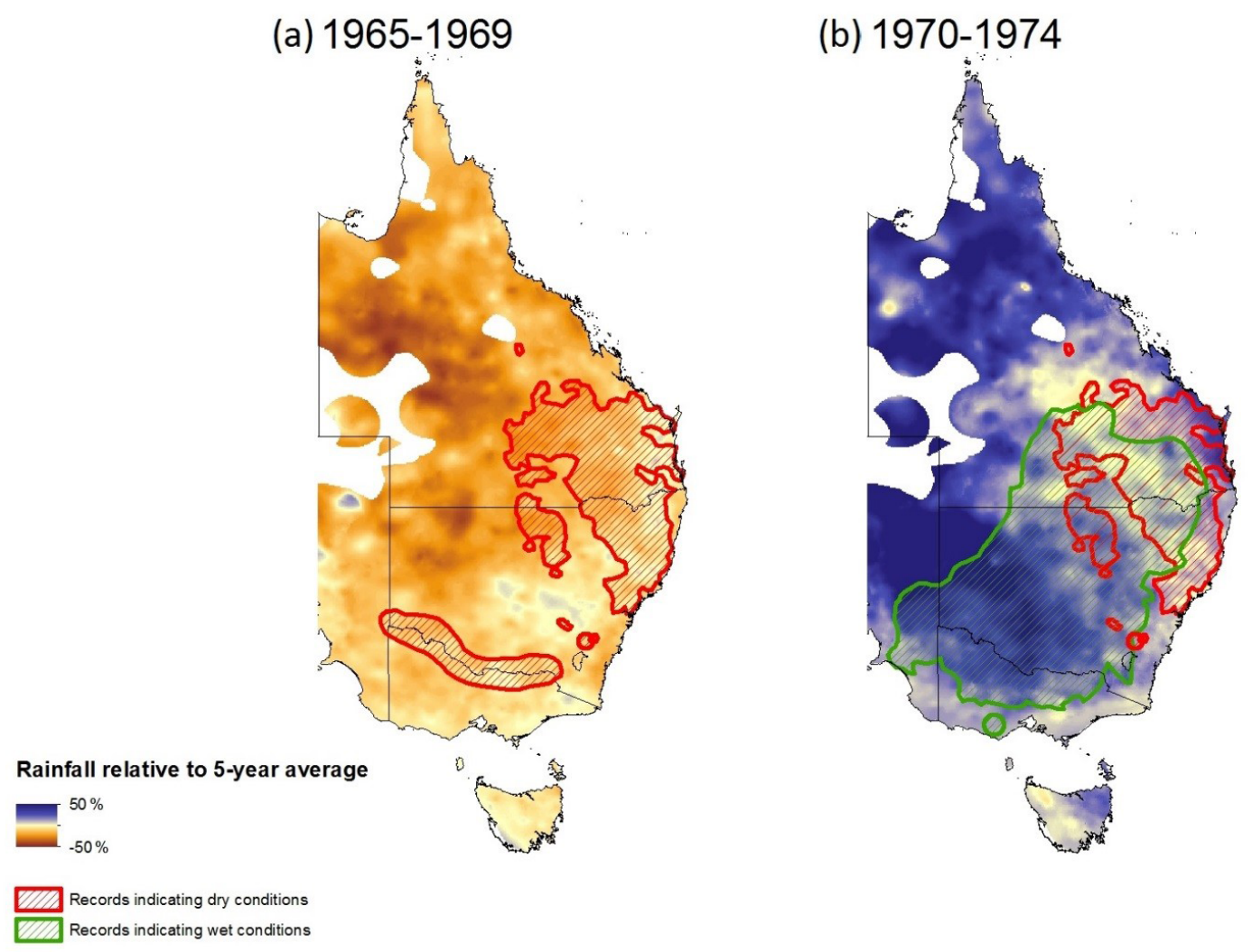

Figure 7. Australian Water Availability Project (AWAP) rainfall anomaly maps of 1965-1969 and 1970-1974, showing the spatial extent of wet/dry conditions suggested by palaeoclimate reconstructions of corresponding pre-instrumental periods.

its controlled water release (i.e. spilling) was associated with extensive flooding in the Brisbane area, destroying many homes and businesses (http://www.floodcommission. qld.gov.au/, last access: 12 October 2020; Van den Honert and McAneney, 2011; McMahon and Kiem, 2018). According to Fig. 8, there were many times in the past 1000 years in which the case study reservoir used here would have been at capacity, and frequent spilling, often for extended periods, would have been necessary. Whether or not this would lead to flooding and damages similar to, or worse than, those seen in southeast Queensland in 2010-2011 is a question that requires further investigation. Nevertheless, the duration that the reservoir has been at capacity pre-1900 far exceeds anything observed in the instrumental period, and therefore, such situations are unlikely to be accounted for in existing design, planning, and management.

When combined with the projected increases in population and demand for water, it is likely that droughts and floods will have an even greater impact on eastern Australia's water supplies. This again highlights how underprepared water management authorities are with regard to extreme and prolonged wet/dry periods like those identified in the palaeoclimate record.

Though our case study location is eastern Australia, these challenges, and the limitations associated with current meth- ods that depend on instrumental records that are too short to realistically characterise interannual to multi-decadal variability, also apply globally. For example, as summarised in the introduction, palaeoclimate reconstructions from many places around the world (e.g. non-eastern Australia, Asia, USA, Europe, and South America) also demonstrate that, as with eastern Australia, the relatively short instrumental hydroclimatic records (typically available from $\sim 1900$ at best) misrepresent both the range of hydroclimatic variability that is possible and the risks associated with extreme hydrological events (e.g. prolonged drought or flood-dominated epochs). The inadequacies of relying on relatively short instrumental records for drought risk quantification and management and for flood frequency analysis is increasingly being recognised by practitioners. For example, in 2019 the USA Geological Survey released new guidelines for flood frequency analysis (England et al., 2019), the first update in 37 years, that documented for the first time how instrumental and palaeoclimate evidence should be used in flood frequency analysis and flood risk assessments. Canada (Natural Resources Canada, 2019) and Australia (in the recently updated Australian Rainfall and Runoff, http://arr.ga.gov.au/, last access: 12 October 2020) also recognise the need to better account for interannual to multi-decadal variability beyond that seen 


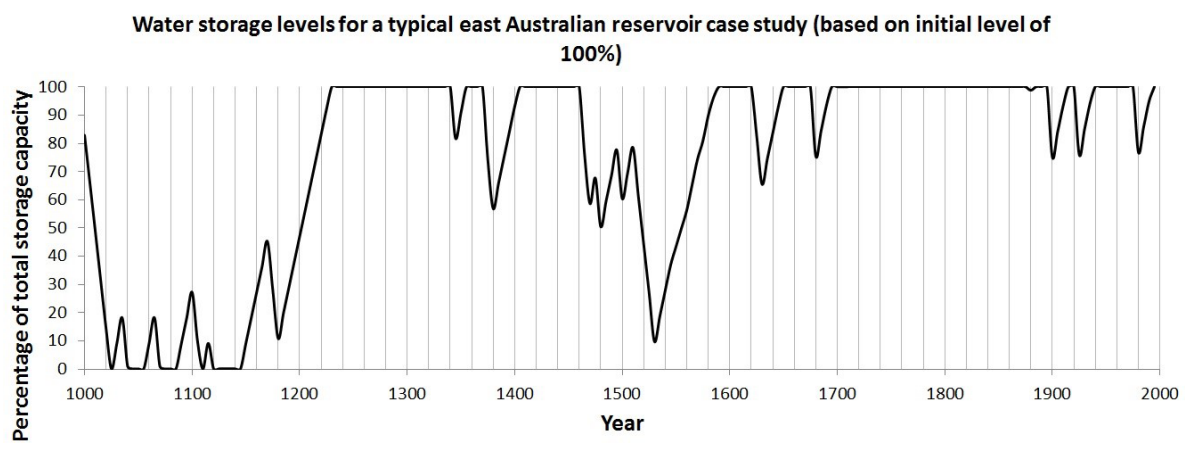

Figure 8. Case study reservoir water storage levels based on initial storage in $1000 \mathrm{CE}$ equal to $100 \%$ of capacity.

in the instrumental records, but limited details are given on how to do this.

\section{Conclusions}

This study suggests that only $29 \%$ of the pre-instrumental period is equivalent to conditions experienced in the instrumental period. This means that $71 \%$ of the pre-instrumental study period has no instrumental equivalent with which to compare it. Therefore, the most important, and concerning, finding from this study is that the range of hydroclimatic conditions experienced in the instrumental period is not indicative of the broader 1000-year period. The proportion, frequency, and duration of wet and dry events in the preinstrumental period is mostly unlike anything experienced instrumentally, and the pre-instrumental records also identify much more severe and prolonged wet/dry epochs. Given that current water resource management strategies are based on the instrumental period only, eastern Australia is probably not equipped to manage water resources during prolonged (i.e. decadal-scale) wet/dry epochs that have occurred in the pre-instrumental period. When coupled with projected impacts of climate change and the demands of a growing population, the impacts of future extreme wet or dry events will likely be significantly greater and more widespread. This represents a significant challenge for water resources and water hazard management in Australia and highlights that infrastructure design and adaptation strategies are probably not as resilient or secure as is suggested by instrumental recordbased risk assessments.

Though our case study location is eastern Australia, there is also evidence in the literature that short instrumental hydroclimatic records misrepresent the range of hydroclimatic variability and risk that is possible in, for example, noneastern Australia, Asia, USA, Europe, and South America. These realities require a paradigm shift from the current practice that assumes probability models calibrated to short instrumental records realistically account for the worst dry or wet epochs possible and that the chance of drought or flood risk does not change over time. These assumptions are clearly incorrect and leave water supply managers without the tools to properly deal with multi-decadal climate variability. Numerous sources of pre-instrumental (palaeoclimate) data (e.g. tree rings, corals, and speleothems) have emerged over the last decade, and more are being worked on currently (e.g. refer to Sect. 4.2 and the Supplement associated with Kiem et al. (2016) for a detailed review and comparison of existing palaeoclimate information relevant to drought in Australia). Palaeoclimate records can extend hydroclimatic records by centuries or millennia, which, as demonstrated here via a simple case study and a deliberately unsophisticated use of palaeoclimate records, can provide new information about which hydroclimatic conditions are plausible (which is potentially of great value to water resources managers and planners). However, palaeoclimate-based reconstructions of past hydroclimatic variability come with their own uncertainties, assumptions, and limitations (e.g. Tozer et al., 2016, 2018; Dixon et al., 2017, 2019; Zhang et al., 2018). Consequently, as also recommended in Kiem et al. (2016), further research is needed to (i) better understand, quantify, and deal with uncertainties and inconsistencies in the palaeoclimate information and (ii) provide the translational science required for water resources managers and planners to maximise the practical value of palaeoclimate records in assessing and managing drought and flood risks.

Data availability. All data used in this paper are publicly available. The palaeoclimate records used were selected from palaeoclimate information available (i.e. published) at the time of study. Refer to Sect. 2 for details of where to access the palaeoclimate information used. Australian Water Availability Project (AWAP) rainfall data are available from the Australian Bureau of Meteorology.

Supplement. The supplement related to this article is available online at: https://doi.org/10.5194/hess-24-5699-2020-supplement.

Author contributions. ALF conducted the review of palaeoclimate literature to identify palaeoclimate data to use, collected palaeo- 
climate data that met the criteria for use in this study, performed the analysis, assisted with writing the original draft and subsequent revisions, and finalised the paper. ASK was responsible for the conceptualisation, methodology, and analysis and assisted with the writing of original draft, subsequent revisions, and finalisation of the paper. TRV and JLR conceptualised the paper, provided the methodology, and collected, developed, and provided the ice core information used in the rainfall reconstruction. JLR provided support with the writing of the draft and the reviewing and editing of the final paper. TRV also assisted with the writing of the original draft and the subsequent revisions and finalisation of the paper. CRT contributed to the methodology, analysis, and writing of the draft and assisted with the reviewing and editing of the paper.

Competing interests. The authors declare that they have no conflict of interest.

Acknowledgements. The authors would like to thank Peter Briggs (CSIRO) for supplying the AWAP data.

Financial support. This research has been supported by the Australian Research Council Discovery project ("Flooding in Australia - are we properly prepared 20 for how bad it can get?"; grant no. ARC DP180102522) and the Australian Research Council Special Research Initiative for Antarctic Gateway Partnership (grant no. SR140300001).

Review statement. This paper was edited by Albrecht Weerts and reviewed by Lisa Davis and one anonymous referee.

\section{References}

Allen, K. J., Lee, G., Ling, F., Allie, S., Willis, M., and Baker, P. J.: Palaeohydrology in climatological context: Developing the case for use of remote predictors in Australian streamflow reconstructions, Appl. Geogr., 64, 132-152, https://doi.org/10.1016/j.apgeog.2015.09.007, 2015a.

Allen, K. J., Nichols, S. C., Evans, R., Cook, E. R., Allie, S., Carson, G., Ling, F., and Baker, P. J.: Preliminary December-January inflow and streamflow reconstructions from tree rings for western Tasmania, southeastern Australia, Water Resour. Res., 51, 54875503, https://doi.org/10.1002/2015wr017062, 2015 b.

Allen, K. J., Nichols, S. C., Evans, R., Allie, S., Carson, G., Ling, F., Cook, E. R., Lee, G., and Baker, P. J.: A 277 year cool season dam inflow reconstruction for Tasmania, southeastern Australia, Water Resour. Res., 53, 400-414, https://doi.org/10.1002/2016wr018906, 2017.

Armstrong, M. S., Kiem, A. S., and Vance, T. R.: Comparing instrumental, palaeoclimate, and projected rainfall data: Implications for water resources management and hydrological modelling, J. Hydrol., 31, 100728, https://doi.org/10.1016/j.ejrh.2020.100728, 2020.
Barr, C., Tibby, J., Gell, P., Tyler, J., Zawadzki, A., and Jacobsen, G. E.: Climate variability in south-eastern Australia over the last 1500 years inferred from the high-resolution diatom records of two crater lakes, Quat. Sci. Rev., 95, 115-131, https://doi.org/10.1016/j.quascirev.2014.05.001, 2014.

Barr, C., Tibby, J., Leng, M. J., Tyler, J. J., Henderson, A. C. G., Overpeck, J. T., Simpson, G. L., Cole, J. E., Phipps, S. J., Marshall, J. C., McGregor, G. B., Hua, Q., and McRobie, F. H.: Holocene El Niño-Southern Oscillation variability reflected in subtropical Australian precipitation, Sci. Rep., 9, 1627, https://doi.org/10.1038/s41598-019-38626-3, 2019.

Barria, P., Peel, M. C., Walsh, K. J. E., and Muñoz, A.: The first 300-year streamflow reconstruction of a high-elevation river in Chile using tree rings, Int. J. Clim., 38, 436-451, https://doi.org/10.1002/joc.5186, 2018.

Buckley, B. M., Ummenhofer, C. C., D’Arrigo, R. D., Hansen, K. G., Truong, L. H., Le, C. N., and Stahle, D. K.: Interdecadal Pacific Oscillation reconstructed from trans-Pacific tree rings: 1350-2004 CE, Clim. Dynam., 53, 3181-3196, https://doi.org/10.1007/s00382-019-04694-4, 2019.

Cook, E. R., Woodhouse, C. A., Eakin, C. M., Meko, D. M., and Stahle, D. W.: Long-Term Aridity Changes in the Western United States, Science, 306, 1015, https://doi.org/10.1126/science.1102586, 2004.

Cook, E. R., Seager, R., Kushnir, Y., Briffa, K. R., Büntgen, U., Frank, D., Krusic, P. J., Tegel, W., van der Schrier, G., AndreuHayles, L., Baillie, M., Baittinger, C., Bleicher, N., Bonde, N., Brown, D., Carrer, M., Cooper, R., Čufar, K., Dittmar, C., Esper, J., Griggs, C., Gunnarson, B., Günther, B., Gutierrez, E., Haneca, K., Helama, S., Herzig, F., Heussner, K.-U., Hofmann, J., Janda, P., Kontic, R., Köse, N., Kyncl, T., Levanič, T., Linderholm, H., Manning, S., Melvin, T. M., Miles, D., Neuwirth, B., Nicolussi, K., Nola, P., Panayotov, M., Popa, I., Rothe, A., Seftigen, K., Seim, A., Svarva, H., Svoboda, M., Thun, T., Timonen, M., Touchan, R., Trotsiuk, V., Trouet, V., Walder, F., Ważny, T., Wilson, R., and Zang, C.: Old World megadroughts and pluvials during the Common Era, Sci. Adv., 1, e1500561, https://doi.org/10.1126/sciadv.1500561, 2015.

Davi, N. K., Pederson, N., Leland, C., Nachin, B., Suran, B., and Jacoby, G. C.: Is eastern Mongolia drying? A long-term perspective of a multidecadal trend, Water Resour. Res., 49, 151-158, https://doi.org/10.1029/2012wr011834, 2013.

Dixon, B. C., Tyler, J. J., Lorrey, A. M., Goodwin, I. D., Gergis, J., and Drysdale, R. N.: Low-resolution Australasian palaeoclimate records of the last 2000 years, Clim. Past, 13, 1403-1433, https://doi.org/10.5194/cp-13-1403-2017, 2017.

Dixon, B. C., Tyler, J. T., Henley, B. J., and Drysdale, R.: Regional patterns of hydroclimate variability in southeastern Australia over the past 1200 years, Earth Space Sci. Open Arc., 32, https://doi.org/10.1002/essoar.10501482.10501481, 2019.

England Jr, J. F., Cohn, T. A., Faber, B. A., Stedinger, J. R., Thomas Jr, W. O., Veilleux, A. G., Kiang, J. E., and Mason, J. R. R.: Guidelines for determining flood flow frequency - Bulletin 17C. available at: https://pubs.er.usgs.gov/publication/tm4B5 (last access: 12 October 2020), Reston, VA, Report 4-B5, 168, 2019.

Feng, S., Hu, Q., Wu, Q., and Mann, M. E.: A Gridded Reconstruction of Warm Season Precipitation for Asia Spanning the Past Half Millennium, J. Climate, 26, 2192-2204, https://doi.org/10.1175/JCLI-D-12-00099.1, 2013. 
Fernández, A., Muñoz, A., González-Reyes, Á., Aguilera-Betti, I., Toledo, I., Puchi, P., Sauchyn, D., Crespo, S., Frene, C., Mundo, I., González, M., and Vignola, R.: Dendrohydrology and water resources management in south-central Chile: lessons from the Río Imperial streamflow reconstruction, Hydrol. Earth Syst. Sci., 22, 2921-2935, https://doi.org/10.5194/hess-22-2921-2018, 2018.

Gallant, A. J. E. and Gergis, J.: An experimental streamflow reconstruction for the River Murray, Australia, 1783-1988, Water Resour. Res., 47, https://doi.org/10.1029/2010wr009832, 2011.

Gallant, A. J. E., Phipps, S. J., Karoly, D. J., Mullan, A. B., and Lorrey, A. M.: Nonstationary Australasian Teleconnections and Implications for Paleoclimate Reconstructions, J. Climate, 26, 8827-8849, https://doi.org/10.1175/jcli-d-12-00338.1, 2013.

Hanel, M., Rakovec, O., Markonis, Y., Máca, P., Samaniego, L., Kyselý, J., and Kumar, R.: Revisiting the recent European droughts from a long-term perspective, Sci. Rep., 8, 9499, https://doi.org/10.1038/s41598-018-27464-4, 2018.

Heinrich, I., Weidner, K., Helle, G., Vos, H., Lindesay, J., and Banks, J. C. G.: Interdecadal modulation of the relationship between ENSO, IPO and precipitation: insights from tree rings in Australia, Clim. Dynam., 33, 63-73, https://doi.org/10.1007/s00382-009-0544-5, 2009.

Hendy, E. J., Gagan, M. K., and Lough, J. M.: Chronological control of coral records using luminescent lines and evidence for non-stationary ENSO teleconnections in northeast Australia, The Holocene, 13, 187-199, https://doi.org/10.1191/0959683603hl606rp, 2003.

Ho, M., Verdon-Kidd, D. C., Kiem, A. S., and Drysdale, R. N.: Broadening the spatial applicability of paleoclimate information - a case-study for the Murray-Darling Basin, Australia, J. Climate, 27, 2477-2495, 2014.

Ho, M., Kiem, A. S. and Verdon-Kidd, D. C.: A paleoclimate rainfall reconstruction in the Murray-Darling Basin (MDB), Australia: 1. Evaluation of different paleoclimate archives, rainfall networks and reconstruction techniques, Water Resour. Res., 51, https://doi.org/10.1002/2015WR017058, 2015a.

Ho, M., Kiem, A. S. and Verdon-Kidd, D. C.: A paleoclimate rainfall reconstruction in the Murray-Darling Basin (MDB), Australia: 2. Assessing hydroclimatic risk using preinstrumental information on wet and dry epochs, Water Resour. Res., 51, https://doi.org/10.1002/2015WR017059, 2015b.

Holland, G. J., Lynch, A. H., and Leslie, L. M.: Australian EastCoast Cyclones, Part I: Synoptic Overview and Case Study, Mon. Weather Rev., 115, 3024-3036, https://doi.org/10.1175/15200493(1987)115<3024:Aeccpi>2.0.Co;2, 1987.

Johnson, F., White, C. J., van Dijk, A., Ekstrom, M., Evans, J. P., Jakob, D., Kiem, A. S., Leonard, M., Rouillard, A., and Westra, S.: Natural hazards in Australia: floods, Clim. Change, 139, 2135, https://doi.org/10.1007/s10584-10016-11689-y, 2016.

Jones, D. A., Wang, W., and Fawcett, R.: High-quality spatial climate data-sets for Australia, Australian Meteorological and Oceanographic Journal, 58, 233-248, https://doi.org/10.22499/2.5804.003, 2009.

Kiem, A. S. and Franks, S. W.: Multi-decadal variability of drought risk - Eastern Australia, Hydrol. Proc., 18, 2039-2050, 2004.

Kiem, A. S., Franks, S. W., and Verdon, D. C.: Climate variability in the land of fire and flooding rain, Australian Journal of Emergency Management, 21, 52-56, 2006.
Kiem, A. S.: Drought and water policy in Australia: challenges for the future illustrated by the issues associated with water trading and climate change adaptation in the Murray-Darling Basin, Glob. Environ. Change, 23, 1615-1626, 2013.

Kiem, A. S. and Austin, E. K.: Drought and the future of rural communities: opportunities and challenges for climate change adaptation in regional Victoria, Australia, Glob. Environ. Change, 23, 1307-1316, https://doi.org/10.1016/j.gloenvcha.2013.1306.1003, 2013.

Kiem, A. S., Johnson, F., Westra, S., van Dijk, A., Evans, J. P., O’Donnell, A., Rouillard, A., Barr, C., Tyler, J., Thyer, M., Jakob, D., Woldemeskel, F., Sivakumar, B., and Mehrotra, R.: Natural hazards in Australia: droughts, Climatic Change, 139, 37-54, https://doi.org/10.1007/s10584-016-1798-7, 2016.

Kiem, A. S., Vance, T. R., Tozer, C. R., Roberts, J. L., Dalla Pozza, R., Vitkovsky, J., Smolders, K., and Curran, M. A. J.: Learning from the past - Using palaeoclimate data to better understand and manage drought in South East Queensland (SEQ), Australia, J. Hydrol., 29, 100686, https://doi.org/10.1016/j.ejrh.2020.100686, 2020.

King, A. D., Alexander, L. V., and Donat, M. G.: The efficacy of using gridded data to examine extreme rainfall characteristics: a case study for Australia, Int. J. Clim., 33, 2376-2387, https://doi.org/10.1002/joc.3588, 2013.

Lara, A., Villalba, R., and Urrutia, R.: A 400-year tree-ring record of the Puelo River summer-fall streamflow in the Valdivian Rainforest eco-region, Chile, Clim. Change, 86, 331-356, https://doi.org/10.1007/s10584-007-9287-7, 2008.

Littell, J. S., Pederson, G. T., Gray, S. T., Tjoelker, M., Hamlet, A. F., and Woodhouse, C. A.: Reconstructions of Columbia River streamflow from tree-ring chronologies in the Pacific Northwest, USA, J. Am Water. Resour. As., 52, 1121-1141, https://doi.org/10.1111/1752-1688.12442, 2016.

Lough, J. M.: Great Barrier Reef coral luminescence reveals rainfall variability over northeastern Australia since the 17th century, Paleoceanography, 26, https://doi.org/10.1029/2010pa002050, 2011.

Martin, J. T., Pederson, G. T., Woodhouse, C. A., Cook, E. R., McCabe, G. J., Wise, E. K., Erger, P., Dolan, L., McGuire, M., Gangopadhyay, S., Chase, K., Littell, J. S., Gray, S. T., George, S. S., Friedman, J., Sauchyn, D., Jacques, J. S., and King, J.: 1200 years of Upper Missouri River streamflow reconstructed from tree rings, Quat. Sci. Rev., 224, 105971, https://doi.org/10.1016/j.quascirev.2019.105971, 2019.

McDonald, J., Drysdale, R., Hill, D., Chisari, R., and Wong, H.: The hydrochemical response of cave drip waters to sub-annual and inter-annual climate variability, Wombeyan Caves, SE Australia, Chem. Geol., 244, 605623, https://doi.org/10.1016/j.chemgeo.2007.07.007, 2007.

McGowan, H. A., Marx, S. K., Denholm, J., Soderholm, J., and Kamber, B. S.: Reconstructing annual inflows to the headwater catchments of the Murray River, Australia, using the Pacific Decadal Oscillation, Geophys. Res. Lett., 36, https://doi.org/10.1029/2008gl037049, 2009.

McMahon, G. M. and Kiem, A. S.: Large floods in South East Queensland, Australia: is it valid to assume they occur randomly?, Australian Journal of Water Resources, 22, 4-14, https://doi.org/10.1080/13241583.13242018.11446677, 2018. 
Natural Resources Canada: Federal hydrologic and hydraulic procedures for floodplain delineation; Natural Resources Canada; Public Safety Canada, Natural Resources Canada, General Information Product 113e, (ed. version 1.0), (Open Access), https://doi.org/10.4095/299808, 61 pp., 2019.

Neukom, R., Gergis, J., Karoly, D. J., Wanner, H., Curran, M., Elbert, J., González-Rouco, F., Linsley, B. K., Moy, A. D., Mundo, I., Raible, C. C., Steig, E. J., van Ommen, T., Vance, T., Villalba, R., Zinke, J., and Frank, D.: Inter-hemispheric temperature variability over the past millennium, Nat. Clim. Change, 4, 362-367, https://doi.org/10.1038/nclimate2174, 2014.

Nguyen, H. T. T. and Galelli, S.: A Linear Dynamical Systems Approach to Streamflow Reconstruction Reveals History of Regime Shifts in Northern Thailand, Water Resour. Res., 54, 2057-2077, https://doi.org/10.1002/2017wr022114, 2018.

Palmer, J. G., Cook, E. R., Turney, C. S. M., Allen, K., Fenwick, P., Cook, B. I., O'Donnell, A., Lough, J., Grierson, P., and Baker, P.: Drought variability in the eastern Australia and New Zealand summer drought atlas (ANZDA, CE 1500-2012) modulated by the Interdecadal Pacific Oscillation, Environ. Res. Lett., 10, 124002, https://doi.org/10.1088/1748-9326/10/12/124002, 2015.

Pederson, N., Hessl, A. E., Baatarbileg, N., Anchukaitis, K. J., and Di Cosmo, N.: Pluvials, droughts, the Mongol Empire, and modern Mongolia, P. Natl. Acad. Sci. USA, 111, 4375, https://doi.org/10.1073/pnas.1318677111, 2014.

Perşoiu, A., Onac, B. P., Wynn, J. G., Blaauw, M., Ionita, M., and Hansson, M.: Holocene winter climate variability in Central and Eastern Europe, Sci. Rep., 7, 1196, https://doi.org/10.1038/s41598-017-01397-w, 2017.

Pui, A., Lal, A., and Sharma, A.: How does the Interdecadal Pacific Oscillation affect design floods in Australia?, Water Resour. Res., 47, https://doi.org/10.1029/2010wr009420, 2011.

Rao, M. P., Cook, E. R., Cook, B. I., Palmer, J. G., Uriarte, M., Devineni, N., Lall, U., D'Arrigo, R. D., Woodhouse, C. A., Ahmed, M., Zafar, M. U., Khan, N., Khan, A., and Wahab, M.: Six Centuries of Upper Indus Basin Streamflow Variability and Its Climatic Drivers, Water Resour. Res., 54, 5687-5701, https://doi.org/10.1029/2018wr023080, 2018.

Robeson, S. M., Maxwell, J. T., and Ficklin, D. L.: Bias Correction of Paleoclimatic Reconstructions: A New Look at 1,200+ Years of Upper Colorado River Flow, Geophys. Res. Lett., 47, e2019GL086689, https://doi.org/10.1029/2019gl086689, 2020.
Tozer, C. R., Kiem, A. S., and Verdon-Kidd, D. C.: On the uncertainties associated with using gridded rainfall data as a proxy for observed, Hydrol. Earth Syst. Sci., 16, 1481-1499, https://doi.org/10.5194/hess-16-1481-2012, 2012.

Tozer, C. R., Vance, T. R., Roberts, J. L., Kiem, A. S., Curran, M. A. J., and Moy, A. D.: An ice core derived 1013year catchment-scale annual rainfall reconstruction in subtropical eastern Australia, Hydrol. Earth Syst. Sci., 20, 1703-1717, https://doi.org/10.5194/hess-20-1703-2016, 2016.

Tozer, C. R., Kiem, A. S., Vance, T. R., Roberts, J. L., Curran, M. A. J., and Moy, A. D.: Reconstructing pre-instrumental streamflow in Eastern Australia using a water balance approach, J. Hydrol., 558, 632-646, 2018.

Urrutia, R. B., Lara, A., Villalba, R., Christie, D. A., Le Quesne, C., and Cuq, A.: Multicentury tree ring reconstruction of annual streamflow for the Maule River watershed in south central Chile, Water Resour. Res., 47, https://doi.org/10.1029/2010wr009562, 2011.

Van den Honert, R. C. and McAneney, J.: The 2011 Brisbane Floods: Causes, Impacts and Implications, Water, 3, 1149-1173, https://doi.org/10.3390/w3041149, 2011.

Vance, T. R., Ommen, T. D. V., Curran, M. A. J., Plummer, C. T., and Moy, A. D.: A Millennial Proxy Record of ENSO and Eastern Australian Rainfall from the Law Dome Ice Core, East Antarctica, J. Climate, 26, 710-725, https://doi.org/10.1175/jclid-12-00003.1, 2013.

Vance, T. R., Roberts, J. L., Plummer, C. T., Kiem, A. S., and van Ommen, T. D.: Interdecadal Pacific variability and eastern Australian mega-droughts over the last millennium, Geophys. Res. Lett., 41, https://doi.org/10.1002/2014GL062447, 2015.

Verdon-Kidd, D. C., and Kiem, A. S.: Nature and causes of protracted droughts in Southeast Australia - Comparison between the Federation, WWII and Big Dry droughts, Geophys. Res. Lett., 36, L22707, https://doi.org/10.1029/2009GL041067, 2009.

Wang, J. K., Johnson, K. R., Borsato, A., Amaya, D. J., Griffiths, M. L., Henderson, G. M., Frisia, S., and Mason, A.: Hydroclimatic variability in Southeast Asia over the past two millennia, Earth Planet. Sci. Lett., 525, 115737 , https://doi.org/10.1016/j.epsl.2019.115737, 2019.

Zhang, L., Kuczera, G., Kiem, A. S., and Willgoose, G.: Using paleoclimate reconstructions to analyse hydrological epochs associated with Pacific decadal variability, Hydrol. Earth Syst. Sci., 22, 6399-6414, https://doi.org/10.5194/hess-22-6399-2018, 2018. 